\author{
AdrianNa AdameK-ŚwiechowsKa \\ (Uniwersytet Gdański)
}

\title{
Przekleństwo niespełnienia w Lux in tenebris lucet Henryka Sienkiewicza
}

\begin{abstract}
Kto wszedł w podziemie, tego otacza ciemność, ale ten nie ma jeszcze prawa przeczyć, że ponad sklepieniem istnieje niebo i słońce, światło i ciepło.
\end{abstract}

Henryk Sienkiewicz ${ }^{1}$

Z doniesień w listach Henryka Sienkiewicza wynika, że twórca wyróżniał w swym dorobku pisaną dla „Biblioteki Warszawskiej” w listopadzie 1890 r. - przed wyprawą do Afryki - nowelę Lux in tenebris lucet. Oferując ją także „Słowu”, zapowiadał Mścisławowi Godlewskiemu: „o ile mogę sądzić, będzie jedną z najlepszych, jakie napisałem”2. Rychło zyskał potwierdzenie od wydawców pierwodruku, Władysława Bogusławskiego i Dionizego Henkiela, że jego odczucie nie było chybione ${ }^{3}$. Podróżującego po Czarnym Lądzie autora dobiegały wieści o artystycznych

${ }^{1}$ Cyt. za: W. Kucharski, Myśli z pism Sienkiewicza, Lwów-Warszawa-Kraków 1926, s. 21.

2 H. Sienkiewicz, List do Mścisława Godlewskiego z 6 XI 1890 r., [w:] tenże, Listy, red. J. Krzyżanowski, oprac. i wstęp M. Bokszczanin t. I, cz. 2, Warszawa 1977, s. 127. Nowela ukazała się w styczniowym zeszycie „Biblioteki Warszawskiej” w 1891 r.

3 Sienkiewicz odnotował w listach do Mścisława Godlewskiego: „Żebyś wiedział, co za list napisał mi ten Bogusławski o Lux in tenebris! Powiada, że z nowel moich ta jest najlepsza”; „Bogusławski i Henkiel popisali mi tak niesłychane rzeczy o tym, iż poczynam wierzyć, że to jest dobre" (H. Sienkiewicz, Listy do Mścisława Godlewskiego z 19 XII 1890 r. i 31 I 1891 r., [w:] tenże, Listy, t. I, cz. 2, s. 144 i 150). 
wrażeniach, jakie wywierała nowela na krytykach i czytelnikach. Okazywało się, że słusznie w chwili ukończenia, czyli 28 listopada, kwalifikował ją w liście do szwagierki, Jadwigi Janczewskiej, jako utwór „dziwny i bardzo oryginalny” ${ }^{\prime}$. Wyjątkowość utworu polegała w jego mniemaniu między innymi na podjęciu problematyki eschatologicznej, a więc obszaru bytu, do zgłębienia którego nie aspirowała literatura realistyczna w okresie pozytywizmu. Trudno uchwytne, niedostępne rozumowi kwestie metafizyczne jako nieosiaggalne szczeble poznania przekraczały konwencje literackie epoki. Sienkiewicz był przekonany, że dokonywał pewnego przełomu estetycznego w literaturze, przyczyniając się do „Zwrócenia ludzi w kierunku idealnym”. Refleksja zawarta w liście do Konrada Górskiego z 14 VII 1894 r. wskazuje zatem na to, że nowelę Lux in tenebris lucet traktować można jako utwór świadomie poprowadzony wbrew racjonalnym prądom epoki ${ }^{6}$. Była to w dorobku autora Trylogii pierwsza nowela poświęcona dociekaniu tajemnic zaświatów. Następne małe formy, w jakich poruszył pisarz tematykę eschatologiczną, powstały już po upływie dekady i przyjęły formę paraboliczną: to Dwie tąki (1903) oraz Diokles (1906). Warto też nadmienić, iż Sienkiewicz przyznawał, że ze wszystkich tytułów własnych utworów - jak przekazał Józef Birkenmajer - „najbardziej mu się podoba Lux in tenebris lucet" ". Wynikało to nade wszystko z predylekcji pisarza do formuł łacińskich, ale w tym wypadku także z poczucia odpowiedniości tytułowego wyrażenia do literackiego obrazu.

Napływające do Sienkiewicza komentarze na temat Lux in tenebris lucet dowodziły, że nie mylił się w swej kwalifikacji - nowela wzbudzała uznanie także z uwagi na estetyczną kreację świata przedstawionego, decydującą o jej oryginalności. Pisarza cieszyły potwierdzenia jej artyzmu:

W Suezie doszly mnie znowu zachwyty bez miary nad Lux in tenebris lucet. Szczególniej zachwyca zestawienie ciemności ziemskich ze światłem empirejskim. Henkiel

${ }^{4}$ Tenże, List do Jadwigi Janczewskiej z 28 XI 1890 r., [w:] tenże, Listy, t. II, cz. 2, oprac. M. Bokszczanin, Warszawa 1996, s. 380.

5 Tenże, List do Konrada Górskiego z 14 VII 1894 r., [w:] tenże, Listy, t. I, cz. 2, s. 293.

${ }^{6}$ Perspektywę metafizyczną Sienkiewicz uwzględniał w kolejnych nowelach i powieściach. W przywołanym liście nie wymienił Lux in tenebris lucet, ale zaznaczył, że w poszczególnych swych dziełach realizował konsekwentnie tendencję idealistyczną, przeciwstawiającą się „estetyce przeglądowo-pozytywnej”. Tamże.

7 J. Birkenmajer, Prace o Sienkiewiczu, „Pamiętnik Literacki” 1935, z. 3-4, s. 613. 
pisał mi, że zakończenie podnosi początek, a początek zakończenie i że rzecz jest nieporównana jako poezja ${ }^{8}$.

Obrazowanie w tej małej prozie, mieszczącej się w jednym odcinku - co pozwalało na pełne dostrzeżenie spójności struktury artystycznej tekstu ${ }^{9}$ - podlegało wysokiej ocenie także historyków literatury. Reprezentatywna pod tym względem jest opinia Juliana Krzyżanowskiego, który napisał o noweli, że jest „drobnym, a niedocenionym arcydziełem, rodzajem mistrzowskiej akwaforty literackiej, operującej nastrojem i światłocieniem" ${ }^{10}$. Piotr Chmielowski, potwierdzając artyzm propozycji, dowodził, że Sienkiewicz osiąga najlepsze efekty w tych utworach, „W których przemagają uczucia miękkie, tęskne, rzewne"11. Interesowały autora Lux in tenebris lucet wielkie dramaty uczuć, w nich bowiem odzwierciedla się świat ideałów. Pod wpływem wrażeń wywołanych obrazem Manon Lescaut Dagnana-Bouvereta, ilustrującym „rozdzierający serce dramat” z opowieści Prévosta, Sienkiewicz w Liście paryskim z 1878 r. stwierdzi1:

Prosta ta i żałobna kronika miłości przemawia do każdej wyższej duszy, szczęśliwej i nieszczęśliwej, wzrusza każde serce szlachetne, pragnące wierzyć, że ponad tym światem płaskim, zwietrzałym, nudnym, kłamliwym jest jeszcze coś świętego, coś wyższego, coś nieśmiertelnego, dla czego żyć warto, a jest to miłość prawdziwa ${ }^{12}$.

Prawdziwe dzieło sztuki zdolne jest bowiem, według pisarza, do wyrażania „najszlachetniejszych porywów piersi ludzkiej” ${ }^{13}$. Zadaniem artysty jest kreowanie arcydzieł tak, by „nieszczęście jako dusza wszystkiego, jako ogólna idea obrazu [była - przyp. A.A.-Ś.] oddana z takim

${ }^{8}$ H. Sienkiwicz, List do Jadwigi Janczewskiej z 4 II 1891 r., [w:] tenże, Listy, t. II, cz. 2, s. 417.

9 Sienkiewicz zalecał druk całości tekstu w jednym odcinku, przestrzegając: „byłaby zaś całkowicie zepsutą, gdybyście ją dzielili” (H. Sienkiewicz, List do Mścisława Godlewskiego z 6 XII 1890 r., [w:] tenże, Listy, t. I, cz. 2, s. 140). Przedruk dokonany w „Słowie” 29 stycznia 1891 r. ukazał się, zgodnie ze wskazówkami autora, w jednym numerze na dwóch stronicach, w formie podwójnego felietonu.

${ }^{10}$ J. Krzyżanowski, Twórczość Henryka Sienkiewicza, Warszawa 1973, s. 315.

11 P. Chmielowski, Henryk Sienkiewicz w oświetleniu krytycznym, Lwów 1901, s. 31.

${ }_{12}$ H. Sienkiewicz, Dzieta, red. J. Krzyżanowski, t. 44: Listy z podróży i wycieczek, Warszawa 1950, s. 94-95.

${ }^{13}$ H. Sienkiewicz, Mowa na odstonięcie pomnika Adama Mickiewicza w Warszawie, [w:] tenże, Dzieta, t. 40: Wiersze i inne drobne utwory, Warszawa 1951, s.79. 
uczuciem i mocą, że ludzie stojący przed obrazem, zamiast mówić, szepcą i oddalają się z ciężkim sercem"14.

Sienkiewicz przywiązywał szczególną wagę do omawianej nowelistycznej miniatury także z uwagi na podjęcie w niej wątków osobistych, związanych z krytycznym momentem swojego życia. Prezentacja życia psychicznego dogasającego $\mathrm{w}$ samotności artysty $\mathrm{w}$ Lux in tenebris lucet bezsprzecznie łączyła się z osobistym doznaniem utraty ukochanej żony, Marii z Szetkiewiczów, zmarłej przedwcześnie na skutek gruźlicy 19 października 1885 r. Był to dla Sienkiewicza, jak trafnie ujmowano w nekrologach, „cios niepowetowany”, gdyż pisarz „skupił w przywiązaniu do towarzyszki życia wszystkie szlachetne sercowe aspiracje”, „czerpał w niepospolitej inteligencji pokrewnej sobie indywidualności, w niezwykłym wykształceniu otuchę i coraz nowe bodźce do twórczości poetyckiej"15. O tym powinowactwie idealistycznych twórczych osobowości przekonuje chociażby zestawienie zapisów listowych młodego Henryka i panieńskich wpisów diariuszowych Maryni. Przyszły pisarz, przygotowując się do egzaminów wstępnych do Szkoły Głównej, snuł ambitne plany twórcze, zaangażowania $\mathrm{w}$ walkę „w imieniu tego, co nazywają idealnym, pięknym i dobrym" ${ }^{16}$. Z dziennika Szetkiewiczówny wyłania się podobna osobowość - aspirująca do rozwoju umysłowego, o wzniosłych zapatrywaniach, „marząca - wedle własnych jej słów - o jakichś nadzwyczajnościach, o swobodzie, uniwersytecie, sławie" ${ }^{17}$, a zatem o tym, by wypełnić życie nauką i „myślami wzniosłymi o sztuce" ${ }^{18}$, „uczyć się, uczyć, a potem zostać autorką” ${ }^{19}$. Można w postaci Kamionki, kochającego nad życie swoją żonę, nierozerwanie z nią związanego, nieumiejącego odnaleźć się w życiu po jej śmierci, widzieć figurę pisarza, a więc sytuować podjęty w noweli temat utraty bliskiej osoby w kontekście biograficznym autora. Nowela miała być ekspresją uczuć, prowadzącą do kompensacji straty i poszukiwania pocieszenia. Intro-

${ }_{14}$ H. Sienkiewicz, Dzieta, t. 44: Listy z podróży i wycieczek, s. 97.

15 Wspomnienie pośmiertne, „Kurier Warszawski” 1885, nr 291a, s. 2. Zob. też: J. Krzyżanowski, Henryk Sienkiewicz. Kalendarz życia i twórczości, uzup. i oprac. M. Bokszczanin, Warszawa 2012, s. 136.

${ }^{16}$ H. Sienkiewicz, List do Konrada Dobrskiego z 16 XII 1965 r., [w:] tenże, Listy, t. I, cz. 1, oprac. M. Bokszczanin, Warszawa 1977, s. 296.

17 M. Szetkiewicz, Dziennik, rękopis w zbiorach Muzeum Henryka Sienkiewicza w Oblęgorku, k. 51. Składam serdeczne podziękowanie paniom Lidii Putowskiej i Małgorzacie Gorzelak za udostępnienie mi diariusza podczas kwerendy w 2008 r.

18 Tamże, k. 38.

19 Tamże, k. 72. 
spekcje cierpiącego, medytacje o sensie życia, rozważania egzystencjalne rodzące się po stracie żony przyjąć można jako transpozycję osobistych emocji twórcy opłakującego zmarłą.

Na powstaniu utworu zaważyła także, wedle legendy rodziny Leów, potrzeba konsolacyjnego oddziałania na przyjaciela Sienkiewicza Edwarda, którego spotkała analogiczna rodzinna tragedia:

Po śmierci matki mojej w styczniowym numerze „Biblioteki Warszawskiej” wyszła nowela Lux in tenebris lucet. Sienkiewicz napisał do ojca mego z Włoch, gdzie przebywał wówczas, żeby przeczytał tę nowelę, bo była z myślą o nim pisana. Z największym wzruszeniem przypominam sobie ten gest wielkiego twórcy, który, w obcowaniu codziennym, nie okazywał wiele tkliwości ${ }^{20}$.

Jak wskazują zachowane świadectwa, opowieść uzyskiwała uniwersalną wymowę. Osobiste doświadczenie autora stawało się na prawach intymności aktu odbioru udziałem innych osób. Ujęcie losu rzeźbiarza Kamionki, dogorywającego w swej pracowni po śmierci ukochanej żony Zosi, odczytywano nie tylko jako „wyznanie osobiste pisarza”, ale odbicie ogólnoludzkiego dramatu. „Mistrz autoaluzji”, jak w kontekście tego literackiego zabiegu określa Sienkiewicza Tadeusz Bujnicki ${ }^{21}$, był jednak świadom wpływu wykreowanego w noweli obrazu na swych bliskich, którzy podzielali uczucie jego straty. W listach do Jadwigi Janczewskiej uprzedzał siostrę zmarłej: „nie czytaj, bo smutna”"22, innym razem, pragnąc uchronić przed zmartwieniem grono najbliższych osób, towarzyszących Maryni w jej walce o życie, przestrzegał -

${ }^{20}$ A. Leo, Gawęda o niedawnej przesztości, Warszawa 1929, s. 152. Wśród zachowanej korespondencji Sienkiewicza do Edwarda Leo jest list pisany z Neapolu 21 grudnia 1890 r., w którym pojawia się wzmianka o Lux in tenebris lucet, lecz jej treść nie potwierdza wspomnienia Anny Leo. Być może źródłem przekonania autorki o dedykowaniu noweli przyjacielowi jest późniejsza sytuacja lub jest ono świadectwem zindywidualizowanej interpretacji dokonanej przez rodzinę, którą dotknęła podobna tragedia. We wspomnianym okresie Stefania z Zielińskich Leowa żyła, ale istotnie chorowała - Sienkiewicz dopytywał się o nią: "Jak ze zdrowiem Pani? Wiem, że po przejściach w Kal[ten] i zmartwieniach z powodu śmierci Scypiona była gorzej - jakże się teraz ma - i czy latem nie zawadzi o Kalten?” (H. Sienkiewicz, List do Edwarda Leo z 21 XII 1890 r., [w:] tenże, Dzieta, t. 55: Korespondencja I, Warszawa 1951, s. 427 oraz H. Sienkiewicz, Listy, t. III, cz. 1, oprac. M. Bokszczanin, Warszawa 2006, s. 495).

${ }^{21}$ T. Bujnicki, Wstęp, [do:] H. Sienkiewicz, Bez dogmatu, Wrocław 2002, s. XXII.

22 H. Sienkiewicz, List do Jadwigi Janczewskiej z 30 XI 1890 r., [w:] tenże, Listy, t. II, cz. 2, s. 382. 
Załączam list Bogusławskiego [Władysława, krytyka literackiego, redaktora „Biblioteki Warszawskiej” - przyp. A. A.-Ś.], który mi zrobił wielką przyjemność. - Sam pisze, że wpada w liryzm, i wpada. - Bo też to jest istotnie oryginalne - i odchodzi od zwykłego typu nowelek. Mowa o Lux in tenebris lucet. Niech mateczka będzie łaskawa zabrać list do Zakop[anego] dla ojca i Mary, ale niech ani Betsy, ani Mara nie czytają tego, chyba że będą miały dobre nerwy, bo to jest w ogóle może nie smutne, ale wzruszające ${ }^{23}$.

Lektura noweli bez wątpienia unaocznia dramat wewnętrzny, który zachodził w duszy pisarza po zdarzeniu, jakie pięć lat wcześniej, 20 października 1885 r., Wanda Szetkiewiczowa zrelacjonowała w liście do młodszej córki: „Pan Bóg zabrał już naszą Marynię do lepszego świata" ${ }^{24}$. Z powstających w tym czasie literackich odbić osobistych doznań mniemać można, że tej wizji nieśmiertelności „drogiej mateczki” nie przyjmował autor Bez dogmatu (1891) bez zastrzeżeń. Przeżycie śmierci żony wywarło piętno na jego twórczości, co Józef Święcicki określał mianem „kompleksu "głowy najdroższej", wyrażającego się poprzez obecność stałego motywu „utraty i odzyskania swego umiłowania, które urasta do wyżyn czynnika decydującego o szczęściu człowieka" ${ }^{25}$. Nowela Lux in tenebris lucet wiąże się z szerokim nurtem utworów, w jakich dochodzi do głosu introspekcja i medytacja o sensie życia. Umieszczana jest przez badaczy w drugiej fazie nowelistyki Sienkiewicza, kiedy to mała forma prozy zatraca samodzielny charakter i staje się częścią powieści ${ }^{26}$. Oznacza to, że odpowiednio przekształcone wspomnienia autor wyzyskuje wówczas w poszczególnych odsłonach, ściśle ze sobą zespolonych, w tym w formach obszerniejszych: Bez dogmatu i Rodzinie Potanieckich (1893-1894). Poddaje w nich analizie dostrzegane negatywne zjawiska, jakie zdaniem Chmielowskiego stanowiły znamię epoki, w której „myślenie, doprowadzając ludzi do zwątpienia, odbiera im energię, ukazuje marność wszystkiego, co się na świecie dzieje, pogrąża w otchłań apatii,

${ }^{23}$ Tenże, List z Rzymu do Jadwigi Janczewskiej z 16 XII 1890 r., [w:] tenże, Listy, t. II, cz. 2, s. 392.

${ }^{24}$ W. Szetkiewiczowa, List do Jadwigi Janczewskiej z 20 X 1885 r., [w:] M. z Szetkiewiczów Sienkiewiczowa, Listy, oprac. B. Szargot, Piotrków Trybunalski 2012, s. 242.

25 J.M. Święcicki, Mitośnicy „gtowy najdroższej” w „Quo vadis”, „Przegląd Powszechny” 1948, nr 12, s. 388.

${ }^{26}$ T. Bujnicki, Wstęp [do:] H. Sienkiewicz, Wybór nowel i opowiadań, oprac. T. Bujnicki, Wrocław 1988, s. LXXXVIII. 
dręcząc zbiedzoną głowę całym szeregiem zapytań bez odpowiedzi” ${ }^{27}$. Z osobistego nurtu rozważań wyłaniają się myśli Leona Płoszowskiego, do powinowactwa z którym pisarz się czasem przyznawał:

W tej rozeznanej impotencji rozumu ludzkiego leży tragedia. Bo pomijając, że natura nasza duchowa będzie zawsze gwałtu krzyczała o odpowiedź na podobne pytania, toż to przecież są pytania największej wagi realnej, najbardziej człowieka obchodzące. Jeśli po tamtej stronie jest coś, i to coś wieczystego, to nieszczęścia i straty po tej stronie maleją do zera. [...] A filozofia odpowiada: Nie wiem. Człowiek szamocze się w tej wielkiej niewiadomej, czując, że gdyby się mógł na którąkolwiek stronę przechylić, to jednak byłoby mu lepiej i spokojniej ${ }^{28}$.

Podjęcie problemu doniosłych doświadczeń doczesności, skłaniające do rozważań egzystencjalnych, było zatem potrzebą zasadniczą szukania pocieszenia i formą opłakiwania zmarłej.

Dramat przedstawiony w noweli Lux in tenebris lucet rozgrywa się w symbolicznej scenerii pracowni przypominającej klasztorną celę czy „kostnicę"29. W atelier panuje mrok, w jakim bohater tkwi tak, jakby już za życia był w grobie. Rozbudowany opis przestrzeni jest istotnym elementem artystycznego ujęcia. Jak zaznacza Zofia Mocarska-Tycowa, to klucz do zrozumienia "ekstremalnego doświadczenia człowieka” ${ }^{30}$. W klimacie listopadowej ciemności i posępności, jaką kreuje autor od pierwszych słów noweli, objawia się w motywach opisu „piętno pewnej martwoty, jakiegoś kalectwa i ułomności sztuki, niedokonania”, owe komponenty obrazu „naznaczone są wanitatywnością i daremnością" ${ }^{31}$. Przygnębiający obraz pracowni symbolicznie odzwierciedla pejzaż wewnętrzny, w którym dominuje melancholia wspomnień, gorycz z powodu bezpowrotnej straty. Obrazowaniu odpowiada rzeczywiste doznanie Sienkiewicza, gdyż pisanie tekstu przebiegało w Zakopanem, gdzie - jak skarżył się autor - „było ciemno [...], wilgotno, ponuro”"32. Mroczny klimat szarości Zakopanego, często określanego przez pisarza w nawiązaniu

27 P. Chmielowski, dz. cyt., s. 119.

28 H. Sienkiewicz, Bez dogmatu, Warszawa 1985, s. 19.

29 Tenże, Lux in tenebris lucet, [w:] tenże, Dzieta, t. 6: Nowele wspótczesne, Warszawa 1949, s. 103.

30 Z. Mocarska-Tycowa, Tropy przymierzy. O literaturze dziewiętnastowiecznej i miejscach jej zbliżeń z malarstwem, Toruń 2005, s. 172.

31 Tamże.

32 H. Sienkiewicz, List do Jadwigi Janczewskiej z 28 XI 1890 r., [w:] tenże, Listy, t. II, cz. 2, s. 379. Wspominany pobyt w Zakopanem przypadł między 20 a 27 listopada. 
do Odysei jako Kraina Cymeryjska ${ }^{33}$, współgra ze sceną ekspozycji opowiadania:

Ciężka ołowiana mgła wisiała nad ziemią; deszcz nie padał, a mimo tego nawet brukowe kamienie na podwórzu wyglądały jak gąbki nasiąkłe wodą; wszystko było mokre, oślizgłe, przejęte na wskroś wilgocią, której pojedyncze krople, spadając z zagięcia rynien, dzwoniły z jakąś rozpaczliwą jednostajnością, jakby odmierzając ów wlokący się leniwie czas smutku³.

W impresjonistycznym ujęciu sugestywnie odmalowanej przestrzeni kształtuje się metaforyczny obraz męki żywota, na jaki składają się pasma fizycznych i duchowych udręk. Rytm deszczu, zatapiającego ziemię, wyznacza rytm życia zgnębionej cierpieniem, zapadającej na chorobę duszy. Inne znaki krajobrazu rozciągającego się za oknem pracowni, a więc „drzewa z resztkami żółtych liści, o gałęziach czarnych od wilgoci a zarazem nieco zatartych przez mgłę”, „krakanie wron” ${ }^{35}$, jako ekwiwalenty odbieranej z niepokojem rzeczywistości, stanowią projekcję ponadczasowych doznań egzystencjalnych, ewokują myśli o wszechogarniającym przemijaniu i śmierci. W takim pejzażu wewnętrznym, jak to dostrzegał Sienkiewicz w poezji Adama Asnyka, ujawnia się „tajemnicze jakieś wołanie z przestrzeni i ciemności”, „zdaje się wówczas, że to nieskończoność tak woła”, co wskazuje na subtelną wrażliwość, skłaniającą

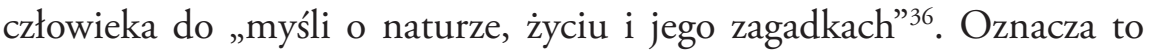
stan alienacji, graniczący z mistycznym usposobieniem, zarówno u powołanej do istnienia kreacji, jak i jej twórcy.

Prezentacja życia psychicznego dogasającego w samotności artysty rozpoczyna się od współbrzmiącej z rozpadem jego świata decyzji o zaprzestaniu pracy nad posągiem Mitosierdzia. Porzucenie dzieła jest objawem braku woli do życia - od tej chwili Kamionka, „przygnębiony, zniechęcony, wyczerpany i smutny" ${ }^{37}$, zaczyna wycofywać się z wszelkiej aktywności, kładzie się do łóżka, rezygnuje z pożywienia, a z czasem zaczyna „myśleć o chorobie jak o czymś pożądanym i pomyślnym”38.

\footnotetext{
33 Tamże.

${ }^{34}$ H. Sienkiewicz, Lux in tenebris lucet, s. 103.

35 Tamże.

${ }^{36}$ H. Sienkiewicz, Dzieta, t. 50: Mieszaniny literacko-artystyczne, Warszawa 1950, s. 6.

37 Tenże, Lux in tenebris lucet, s. 104.

38 Tamże, s. 110.
} 
Jedynym zajęciem bohatera staje się uporczywe wypatrywanie w oknie "choć skrawka błękitnego nieba”39.

Nieskończony posąg Kamionki jest sygnałem rezygnacji z procesu integracji z otaczającym światem, objawem alienacji. Wszak twórcza osobowość - jak twierdzi Anthony Storr - wykorzystuje swój umysł do tego, by „odnaleźć znaczenie istnienia wszechświata poprzez wszystko to, co tworzy" ${ }^{40}$. Sztuka była dla bohatera wyrazem dążenia do wypełnienia pustki emocjonalnej. Przynosiła ratunek, ale nie na długo, bo przekonanie o własnym talencie słabło. Kamionka, mimo nieopuszczającej go melancholii, zdołał wytrwać dwadzieścia lat po śmierci ukochanej. Tworzenie jej pomnika okazało się na pewien czas skutecznym sposobem na odzyskanie utraconej z nią jedności. Proces ten psycholog objaśnia specyfiką umysłu obdarzonego talentem, który „wydaje się tak skonstruowany, że powstanie nowej równowagi lub proces wyzdrowienia dokonujący się w subiektywnym świecie wyobraźni odczuwany jest w taki sposób, jakby także w świecie zewnętrznym dokonała się zmiana na lepsze" ${ }^{11}$. Kamionka pół roku rzeźbił pomnik, a następnie uczucia swoje związał z pasją kolekcjonerską, która kompensowała utratę ukochanej. Od chwili gdy dopatrzył się na starym sztychu wyobrażającym Armidę „podobieństwa do twarzy swej zmarłej” ${ }^{2}$, w gromadzeniu akwafort przedstawiających heroinę Jerozolimy wyzwolonej Torquata Tassa znalazł sposób na wypełnienie pustki po żonie. Zjawisko przeniesienia funkcjonowało jako podświadoma strategia służąca odnalezieniu kontaktu z ukochaną. Owo subtelne nawiązanie do włoskiego poematu wyznacza interesujące tropy interpretacyjne, których dalszy rozbiór pozwala dostrzec pogłębienie psychologiczne kreacji bohatera noweli, w pewnych aspektach odzwierciedlającego przeżycia jej autora ${ }^{43}$.

Trwałemu przezwyciężeniu depresji Kamionki stanęło na przeszkodzie poczucie twórczej niemocy. Zachodzi bowiem istotna złożoność

39 Tamże, s. 103.

40 A. Storr, Samotność. Powrót do jaźni, przeł. J. Prokopiuk i P. Sieradzan, Warszawa 2010, s. 14.

41 Tamże, s. 188.

${ }^{42}$ H. Sienkiewicz, Lux in tenebris lucet, s. 106.

${ }^{43} \mathrm{Na}$ marginesie warto dodać, że w księgozbiorze Henryka Sienkiewicza, zachowanym częściowo w Muzeum w Oblęgorku, znajduje się edycja dzieła Torquata Tassa Goffred albo Jerozolima wyzwolona w adaptacji Piotra Kochanowskiego (Warszawa 1772). Funkcjonalne nawiązanie do tego poematu, należącego niewątpliwie do ulubionych lektur, świadczy o wyznaczeniu mu przez autora Lux in tenebris lucet ważnego miejsca w świadomości literacko-kulturowej. 
powiązań między utratą bliskiej osoby a brakiem osiągnięć twórczych. Gest artystyczny ratował od poczucia bezsilności. Przebywanie w samotności i skupienie na pracy umożliwiało docieranie do wyobraźni, krystalizującej najgłębsze pragnienia. Bohater kochał uwewnętrzniony, przechowywany w duszy obraz żony, ale ten idealny, utrwalony w pamięci wizerunek, podsycany ilustracjami skojarzonej z nią Armidy, był tylko wyobrażeniem. Podobnie jak sam proces tworzenia pomnika, przeciągany w nieskończoność, stwarzał jedynie iluzję szczęścia obcowania $\mathrm{z}$ drogą istotą. Stan pobudzenia wyobraźni i napięcie wewnętrzne utrzymywały bohatera przy woli życia, lecz musiał nastąpić kres na skutek podporządkowania istnienia nieosiągalnym pragnieniom, rodzącym stałe frustracje:

[...] wszystkie jego myśli owinęły się koło wspomnienia o niej i czerpały z niego pokarm, zupełnie jako pasożyta roślina czerpie pokarm z pnia, na którym żyje. Ale z tego rodzaju wspomnień roślina ludzka może czerpać tylko zatrute soki, złożone z żalu i ogromnego zmartwienia, więc też i Kamionka zatruwał się, krzywił i marniał ${ }^{44}$.

Niezwalczone poczucie przywiązania do zmarłej wprowadza bohatera na drogę wyzwalającą śmierć. Nie do końca uświadomiona decyzja o życiu w doskonałej ascezie jest podświadomie formą samobójstwa. Kamionka umiera najpierw dla świata, wyzwalając się z materialnych konieczności swojego istnienia, zaspokajanych w znikomej części, ograniczonych do picia szklanki herbaty podanej przez stróżkę. Żywioł przemiany, który warunkuje wegetację w oczekiwaniu na osiągnięcie stanu harmonii, jak konstatuje Ryszard Koziołek, nieuchronnie prowadzi do „piwnicy grobowej”. Zdaniem badacza, ten rodzaj literackiego ujęcia „może się jawić jako przyznanie sobie prawa do śmierci, które wyraża się w zatrzymaniu życia w kształcie, w którym nie rządzi nim już biologia" ${ }^{\prime 4}$. Sytuacja egzystencjalna Kamionki przywołuje gnostyczne praktyki popełniania samobójstwa poprzez samozagłodzenie. Bohater nie ma innych symptomów choroby jak tylko odraza do życia. Pozostawanie w letargu wyraża w tej koncepcji zachowań ideę „śmierci za życia”. Dla gnostyków, jak przedstawia Stefan Chwin, analizując formy samobójstw w kulturze, asceza zmierzała do pogłębienia uduchowienia; motywowana względami religijnymi prowadziła do „przebóstwienia” ciała, by przejść

${ }^{44}$ H. Sienkiewicz, Lux in tenebris lucet, s. 106.

45 R. Koziołek, Ciata Sienkiewicza, Katowice 2009, s. 203. 
do lepszego istnienia ${ }^{46}$. Kamionka „nie miał ochoty umrzeć” ${ }^{47}$, ale skrajna abnegacja staje się w jego sytuacji rytuałem wyzwalającym śmierć. Zachowanie rzeźbiarza nie jest przy tym wynikiem postawy religijnej, pragnienia „przebicia się przez sfery kosmosu”, by „powrócić do swego boskiego początku”48. Pobożność „z biegiem lat zmieniła się w nim na zwyczaj, polegający na zachowywaniu form zewnętrznych" ${ }^{2}$. Nie wyposażała go ona w etyczne przekonanie o konieczności wyzwolenia duszy z więzów nikczemnej egzystencji, by przenieść ją do lepszego świata. Bohater nie znajduje wsparcia w wierze, która potrafi w sytuacji kryzysu duchowego nadać sens ludzkiemu życiu. U niego rozpacz z powodu utraty miłości eliminuje naturalne determinanty bytu, zagłusza instynkt samozachowawczy. W tym wypadku egzystencja jest nie do zniesienia, bo zabrakło w niej wartości - wiary, nadziei, a miłość została utracona.

Złożoność sytuacji egzystencjalnej bohatera symbolicznie odzwierciedla motyw uporczywego wpatrywania się w okno. Odnosi się wrażenie, że artysta uwięziony w ciemnej, dusznej, zaniedbanej pracowni, będącej niegdyś feerycznym rekwizytorium Hansa Makarta, szuka ratunku. W obrazie literackim dochodzi do głosu duch Kanta, który - jak zauważyła Aneta Mazur - miał decydujący wpływ na zmianę postrzegania sfery transcendentalnej: „zagasił to ufne źródło wiedzy” na temat bytu, jaki w klasycznej metafizyce "dawał się poznać sam przez się; był światłem, które promieniowało na poddający mu się umysł" ${ }^{50}$. Wedle Kantowskiego idealizmu transcendentalnego, bliskiego potem Schopenhauerowi, dyspozycje człowieka ograniczają jego akty poznania do zadawania pytań o nieśmiertelność, o ostateczną przyczynę, ostateczny cel i sens istnienia. W takim stanie tkwi protagonista noweli Sienkiewicza, zatem odpowiada mu charakterystyka obszaru ludzkiego doświadczenia dokonana przez Anetę Mazur:

Byt przestaje być światłem, staje się mrokiem i niepewnością ludzkiego umysłu, bo nie można dowieść istnienia metafizycznego wymiaru - duszy, nieśmiertelności, Boga - w sposób tak pewny jak dowodzone są tezy matematyczne; a innego rodzaju wiedzy pewnej nie $\mathrm{ma}^{51}$.

46 Por. S. Chwin, Samobójstwo i „grzech istnienia”, Gdańsk [2013], s. 88-92.

${ }^{47}$ H. Sienkiewicz, Lux in tenebris lucet, s. 104.

48 S. Chwin, dz. cyt., s. 88-89.

${ }^{4}$ H. Sienkiewicz, Lux in tenebris lucet, s. 106.

50 A. Mazur, Transcendencja realistów. Motywy metafizyczne w polskiej i niemieckiej prozie II potowy XIX wieku, Opole 2001, s. 15.

51 Tamże. 
W ruchu kierowania spojrzeń ku niebu warto dostrzec jego źródło, ściśle powiązane ze światem ostatniej pasji Kamionki. Za pośrednictwem swej miłości upostaciowanej w Armidzie myśl bohatera błądzi w epickim obrazie Tassa, w którym spoglądanie ku niebu - tak w sferze dosłownej, jak i metaforycznej - jest stałą perspektywą penetracji sfery istnienia. W Gofredzie, jak zauważa Beata Cieszyńska, „ludzkie poznanie, zdeterminowane cielesnością, jest niejasne”, „egzystencjalny wysiłek spoglądania ku niebiosom”, oznaczający poszukiwanie pomocy i podporządkowanie swych pragnień antropomorficznie pojmowanemu Bogu, napotyka na zasłonę ${ }^{52}$. Realizacja Owidiańskiego toposu człowieka spoglądającego w niebieski firmament budzi w noweli Sienkiewicza skojarzenia z doświadczonym mocno przez uczucie Rynaldem, który wyraża „głębokie zadziwienie ułomnościami ludzkiego poznania” słowami: „wszyscy się światła chwytamy ciemnego" ${ }^{53}$. Do pracowni Kamionki zagląda tylko mdłe światło listopadowego dnia, animuje ją niepewny, blady płomyk świecy. Można sądzić, że obraz świata przedstawionego w Jerozolimie wyzwolonej opatruje bohatera dodatkowymi znakami wątpienia w skuteczność możliwości poznawczych.

Postaci tytułowego bohatera rysów mógł nadać - według hipotezy Janiny Wiercińskiej - rzeźbiarz Antoni Kurzawa, który, poniósłszy w styczniu 1890 r. porażkę w konkursie na projekt pomnika Adama Mickiewicza w Krakowie, popadł w alkoholizm, depresję i obłęd. Badaczka zaznacza, że w wypadku Sienkiewicza nie może być mowy o dosłownej transpozycji losu konkretnego artysty, bo jego kreacje powstawały z nałożenia się rysów wielu osób, ale zwraca uwagę na podjęcie przez pisarza dość powszechnego w atmosferze dekadenckiej problemu, jakim była nędza egzystencji artysty, zaniedbanego, opuszczonego, samotnego, z czym stykał się w obcowaniu ze światem cyganerii warszawskiej. Ze względu na ten motyw pogrążającego się w abnegacji i umierającego w poczuciu niemocy artysty Janina Wiercińska dostrzega powinowactwo między nowelą Sienkiewicza a rysunkiem na kartonie Antoniego Kamieńskiego Niedokończone dzieto $(1894)^{54}$, ukazującym wstrząsa-

52 B. Cieszyńska, Okna duszy. „Gofred abo Jeruzalem wyzwolona” Tassa-Kochanowskiego w kręgu zmystów, [w:] Z ducha Tassa, red. R. Ocieczek, współudz. B. Mazurkowa, Katowice 1998, s. 148-149.

53 Tamże, s. 148.

${ }^{54}$ Reprodukcja drzeworytnicza tego nagrodzonego w styczniu 1895 r. w konkursie Towarzystwa Zachęty Sztuk Pięknych kartonu Kamieńskiego w wykonaniu drzeworytnika Józefa Holewińskiego ukazała się na łamach „Tygodnika Ilustrowanego” 1895 , nr 40, s. 215. 
jący portret przygnębionego artysty, tkwiącego na nędznym barłogu. W związku z tym uznaje, że literackie dzieło mogłoby z powodzeniem przyjąć tytuł pracy rysownika, bez wątpienia zainspirowanego tekstem ${ }^{55}$. Obraz Niedokończone dzieto wyraziście ujmuje klimat i nastrój sytuacji Kamionki, o czym upewnia jego wnikliwy opis dokonany przez krytyka Cezarego Jellentę:

Pracownia rzeźbiarza: na lewo w półcieniu jakaś ogromna, wyniosła grupa z wielu figur złożona, majacząca konturami klasycznymi, a choć niewyraźna, przecież pełna polotu i patosu. Na prawo zaś, na nędznym barłogu, owinięty kołdrą, siedzi artysta i patrzy spode łba, ponuro i smutno [...]. Rzeźbiarz to więc umierający, zmarnowany przez nędzę i chorobę; ginie zaś na samym progu sławy [...]. A nad samą jego głową przyczepiona do muru uśmiecha się śnieżno-biała gipsowa główka niewieścia, figlarna, naiwna, wesoła... ${ }^{56}$

Sygnał wyżej nakreślonego pokrewieństwa tematycznego - podjęcia motywu artysty, do którego śmierci doprowadza nieukończenie arcydzieła, niespełnienie twórcze - poszerza zakres interpretacji utworu Sienkiewicza. Rzeźbiarz Kamionka staje się figurą świadomego swej ułomności, ogarniętego niemocą i poczuciem niespełnienia twórcy. Aspekt ten nabiera istotnego znaczenia w związku $\mathrm{z}$ tematem porzuconego przez bohatera projektu. Niedokończenie posagu Mitosierdzie jest wymownym znakiem rezygnacji z oczekiwania na ratunek i pogrążenia w rozpaczy, uznaniem, że transcendentalne idee wydają się nierealne i nieosiągalne.

Myśl o nieprzeniknionej przestrzeni jako sygnale odwiecznych tajemnic wszechświata powraca u twórcy Lux in tenebris lucet podczas podróży afrykańskiej, kiedy wrażenia na widok nieskończoności morza czy pustyni wywołują niepokój i grozę:

W pustyni odczujesz wszystko, z czego się składa śmierć, nie odczujesz tylko miłosierdzia. W stężałych wydmach i tym stężałym niebie tkwi coś nieubłaganego. Po prostu mówiąc, ma się to niesłychanie gnębiące wrażenie, że z tego umarłego nieba nikt nie patrzy, że wśród tych płowych piasków nikt nie słyszy i że na pustyni próżno by rozpacz wołała o ratunek ${ }^{57}$.

55 Zob. J. Wiercińka, Sztuka i ksiażka, Warszawa 1986, s. 155-158. Antoni Kamieński był również autorem ilustracji do Lux in tenebris lucet prezentowanych w „Tygodniku Ilustrowanym” w 1896 (nr 51, s. 997) oraz w warszawskim wydaniu Nowel Sienkiewicza z tego samego roku.

56 C. Jellenta, $Z$ powodu konkursu, „Prawda” 1895, nr 4, s. 42-43. Cyt. za: tamże, s. 155.

57 H. Sienkiewicz, Dzieta, t. 43: Listy z Afryki, Warszawa 1949, s. 16. 
Podobne odczucia rodzi obraz księżyca: „bardzo pognębiają myśl ludzką owe pola księżycowe, umarłe, a tak poszarpane, tak dziko bezładne, jakby skonały w konwulsjach" ${ }^{58}$. Refleksje te korespondują z odczuciami wykreowanego tuż przed podróżą rzeźbiarza Kamionki, którego stan odpowiada gęstniejącemu mrokowi pracowni pozbawionej słońca. Migotliwość świecy, będącej jedynym źródłem blasku, odpowiada kruchości dogasającego żywota. Paradoksalnie dopiero po wypaleniu się iskry istnienia izbę obejmuje światło: „mocne, jasne i radosne”, którego fale tworzą „świetlaną przestrzeń bez granic" 59 . Pracownia dematerializuje się, ulega przekształceniu w nadnaturalne przestworze. Bohater umiera, wkraczając wraz ze zjawą żony w empirejską światłość: „po chwili poczęło mu wszystko ginąć z oczu, bo owa otaczająca ich jasność, jakby popychana zaświatowym wiatrem, szła gdzieś w nieskończoność" ${ }^{60}$.

Ulega odwróceniu sytuacja horyzontalna. Bohater, przeciwnie niż w ekspozycji, w finale (po śmierci) z zewnątrz patrzy przez weneckie okno swej pracowni do jej wnętrza, gdzie pozostały jego marne szczątki „Z szeroko otwartymi ustami, które w wyżółkłej twarzy tworzyły jakby czarną jamę" ${ }^{\prime \prime}$. Wizja odlotu duszy otwiera niespodziewanie zamkniętą dotychczas przestrzeń, prowadzi zatem, jak stwierdza Zofia Mocarska-Tycowa, do „metafizycznego otwarcia, transgresji doczesności”"62. Zarysowany „zaświat” - zjawisko, jak podkreśla Anna Martuszewska, "niemieszczące się w pozytywistycznym scjentyzmie" 63 - jest symbolem nieba. W tej formie finał jest przekazem „ukrytej, najistotniejszej wiedzy o świecie” - „prawdy typu objawionego” ${ }^{64}$. Perspektywa poznawcza zdaje się w momencie śmierci poszerzać, ale można zauważyć za Anetą Mazur, iż owa wizja zaświatów przedstawiona w ujęciu lirycznym pozostaje enigmatyczna w określeniu, czym jest nieśmiertelność ${ }^{65}$. Badaczka określa tę właściwość jako dziwiętnastowieczny sposób określania transcendencji, dlatego obrazowanie Sienkiewicza w noweli postrzega jako „najbardziej zdecydowane” w prezentacji sfery metafizycznej. W tym kontekście dodaje jednak:

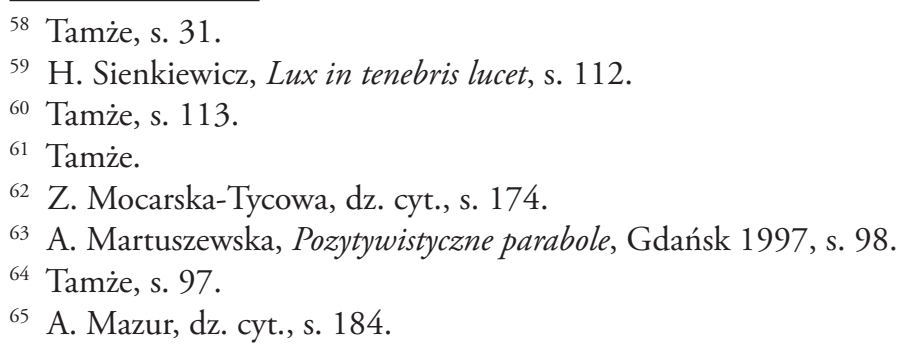


Zaskakująca puenta tekstu próbuje odtworzyć zaskoczenie momentu przejścia i jest to jedyny chyba walor tej konwencjonalnej estetycznie wizji zaświatów, stworzonej jakby specjalnie z myślą o bohaterze artyście ${ }^{66}$.

Dalej badaczka uznaje, że właściwa penetracja obszaru transcendencji następuje w tych powieściach Sienkiewicza, w których pojawiają się ,jedne z niewielu propozycji nazywania po imieniu egzystencji pośmiertnej" w literaturze realistycznej ${ }^{67}$. Emanacja empirejskiego światła $\mathrm{w}$ Lux in tenebris lucet zachowuje zatem nade wszystko sens symboliczny. Mistyczne przeżycie skutkuje doznaniem śmierci - dusze małżonków spotkają się w zaświatach ${ }^{68}$.

Jak wskazuje Beata Obsulewicz-Niewińska, w zarysowanym w noweli oglądzie losu bohatera zasadniczą rolę odgrywa postać szarytki, której najęcie sugeruje stróżka. Zakonnica z racji swych kompetencji miałaby zaoferować nie tylko bezinteresowną pomoc, ale udzielić wsparcia duchowego, umniejszającego ciężar cierpienia. Do spełnienia tej możliwości nie dochodzi, ale w przedśmiertnym widzeniu o brzasku Kamionka spostrzega u swego wezgłowia nieznaną postać kobiecą w kornecie. To właśnie ona, przeobrażając się w anielską zjawę żony, spełnia najważniejszą funkcję - „zwiastuna i posłańca” ${ }^{69}$. Zgodnie z marzeniem rzeźbiarza, by siostra miłosierdzia wniosła otuchę w jego życie, pojawienie się niezwykłej mary wprowadza spodziewany przełom - przynosi światło. W tym spotkaniu „finalizuje się zarówno parogodzinne oczekiwanie na szarytkę, jak i wieloletnie oczekiwanie na uwolnienie przez żonę od brzemienia samotności"70. Przedstawienie wizji służy zatem przede wszystkim opisaniu „niezwykłego stanu w Empireum - doświadczenia pełni i jedności w różnorodności, doświadczenia nadmiaru przystosowanego do ludzkiej tęsknoty" ${ }^{\prime 1}$. Wydobyte z głębin własnej psyche pragnienie szczęścia siłą rzeczy krystalizuje się w sferze metafizycznej.

66 Tamże, s. 185.

67 Tamże.

${ }^{68}$ Koresponduje z tym ujęciem spełnienia miłości przesłanie Kamizelki Bolesława Prusa, operującego podobnym pesymistycznym ujęciem, lecz uwzględniającego optymistyczną metafizyczną perspektywę w finale. Por. B. Bobrowska, Kamizelka czy Śnieg, czyli o "perspektywach na catość bytu”, [w:] taż, Mate narracje Prusa, Warszawa 2003, s. 21-38.

69 B. Obsulewicz-Niewińska, „Nieobatamucona” wrażliwość. Pisarze okresu pozytywizmu o filantropii i mitosierdziu, Lublin 2008, s. 371.

70 Tamże.

71 Tamże. 
Symbolika światła wyłaniającego się z ciemności poprzez odwołanie do Prologu Ewangelii św. Jana (J 1,5) uwypukla sens biblijny, który można odnieść również do każdej pokrewnej sytuacji. Obudzony do życia wiecznego artysta staje się figurą człowieka odnajdującego sens egzystencji. Spełnienie jest możliwe poza światem ziemskim, niczym w krainie baśniowej wyspy szczęśliwej, wyzwolonej z czasu i przemijania. Podobnie jak na bohaterów eposu Tassa, i na Kamionkę przychodzi objawienie przyjęte jako cud; to doświadczenie mistyczne - tajemne moce są „ukryte pod pozorami omylnych zjawisk” ${ }^{2}$. Potęga miłości przekroczyła granice śmierci, ale doprowadziła do samounicestwienia. W świecie Sienkiewiczowskim skazani na kruchą egzystencję kochankowie, jak zauważa Jolanta Sztachelska, mogą się po śmierci połączyć, „jeśli nie w wielkiej pustce, to na tej samej drodze"73.

Miłość w utworach Sienkiewicza, jak akcentował Władysław Bogusławski, „wielką odgrywa rolę”, co autora „oryginalnie wyosabnia spośród tłumu chorych bałwochwalców Erosa w beletrystycznej Europie”, bo oddziałuje jak „czynnik etyczny: podnosi, uszlachetnia, przeobraża, jest kwiatem indywidualności, i dlatego skupiają się w niej [miłości - przyp. A.A.-Ś.] niekiedy wszystkie ideały dobra, prawdy, piękna” - w tym między innymi „umierającemu artyście rozjaśnia mroki konania niebiańską światłością"74. Istotnym aspektem znaczenia miłości w Sienkiewiczowskiej noweli jest uwypuklenie pozytywnej roli kobiety. Jak akcentuje Beata Obsulewicz-Niewińska, „światło wyzwolenia przychodzi dzięki misji żarliwie kochanej kobiety”, która jest „niczym dantowska Beatrycze emisariuszką epifanii, promienieniem wiekuistego światła"75. Objawia się zatem moc oddziaływania miłości, która w każdym aspekcie, nawet w sytuacji niespełnienia i nieosiągalności, przeobraża mężczyznę i podporządkowuje namiętności. Jak wynika z polemiki Stanisława Wyspiańskiego z Sienkiewiczem poświęconej Hektorowi, herosowi Iliady, świat, w którym ma miejsce „uleganie czarowi kobiety”, bliski jest czasom Ariosta, Tassa, a nie

${ }^{72}$ J.K. Goliński, Między niebem a piektem. „Wojna pobożna” bohaterów Tassa-Kochanowskiego, [w:] $Z$ ducha Tassa, s. 126.

73 J. Sztachelska, Dlaczego Hamlet a nie Faust. Motywy Goetheańskie w twórczości Henryka Sienkiewicza, [w:] Postacie i motywy faustyczne w literaturze polskiej, t. II, red. H. Krukowska i J. Ławski, Białystok 2001, s. 21.

${ }^{74}$ W. Bogusławski, Quo vadis Henryka Sienkiewicza, „Biblioteka Warszawska” 1897, t. I, z. 1, s. 96.

75 B. Obsulewicz-Niewińska, dz. cyt., s. 372. 
Homera $^{76}$. Sienkiewicz, afirmując zjawisko miłości, niewątpliwie do tej tradycji nawiązuje, czego istotnym znakiem jest wprowadzenie do noweli Lux in tenebris lucet motywu akwafort $\mathrm{z}$ wizerunkiem czarodziejskiej Armidy. Stanowi to potwierdzenie spójności koncepcji świata przedstawionego, co decyduje z kolei o wiarygodności ujęcia stanu psychofizycznego poprzedzającego śmierć nieszczęśliwego kochanka-artysty.

Z przedstawionym w noweli obrazem kamieniejącego rzeźbiarza ma niewątpliwie związek mistyczna wizja, jaką opisuje Sienkiewicz w liście trzecim z Afryki, tworzonym w okresie, gdy dochodzą go „zachwyty nad Lux in tenebris lucet". W posępnym krajobrazie martwoty uwaga pisarza koncentruje się na egipskim zabytku: rzeźbie Sfinksa. Wzbudza on fascynację; w wyobraźni łączy się z właściwym cywilizacji egipskiej pierwiastkiem magiczności, co skłania do ożywienia głazu poprzez przytoczenie sekretu, który skrywa bliżej nieznana legenda o miłości między Sfinksem i Izys. W liście trzecim, określanym przez pisarza mianem poetyckiego nokturnu, kreuje Sienkiewicz obraz „mistycznego związku między Sfinksem i księżycem" "77. W powiązaniu z funkcjonującym wśród aleksandryjskich marynarzy oraz znanym z traktatu Plutarcha O Izydzie i Ozyrysie ${ }^{78}$ utożsamieniem tajemniczego satelity z bóstwem władającym magią, Izydą, tworzy źródło osnowy legendy o zastygnięciu Sfinksa z powodu niespełnionej miłości. W świetle tej historii Sfinks jawi się jako tajemniczy znak odwiecznej niemożności zrealizowania rozkoszy miłosnej w świecie doczesnym. Kamienna rzeźba staje się alegoryczną figurą, ewokującą los człowieczy, wyrażony w dziejach Kamionki, którego nazwisko i profesja łączą się z metaforycznym tropem interpretacji.

Wrażliwość estetyczna Sienkiewicza konkretyzuje się w postaci umiejętnie transponowanych efektów światłocienia w odniesieniu do konwencji symboliki światła i ciemności. Dzięki temu wprowadza pisarz w sferę ponadczasowych problemów egzystencjalnych. W świetle noweli Lux in tenebris lucet, jak i innych pokrewnych tekstów autora, najważniejszym doświadczeniem ludzkim staje się miłość, której natura, naznaczona niespełnieniem, stawia człowieka przed zagadkami egzystencji, objawia jej znaczenie. Miłość jest motorem prowadzącym do odrodzenia, wyzwolenia z uwikłań materialnego bytu. Odpowiednie operowanie światłocieniem

${ }^{76}$ F. Hoesick, Hektor Sienkiewicza a Wyspiańskiego, [w:] tenże, Sienkiewicz $i$ Wyspiański. Przyczynki i szkice, Kraków 1918, s. 67.

77 H. Sienkiewicz, Dzieta, t. 43: Listy z Afryki, s. 22.

78 Zob. Plutarch, O Izydzie i Ozyrysie, przekł., wstęp i objaśnienia A. Pawlaczyk, Poznań 2003, s. 23. 
prowadzi do refleksji, w tym wypadku nad koniecznością wyzwolenia się z materialnego świata, by móc osiągnąć rajski stan szczęśliwości. Piętnem świata doczesnego jest niedoskonałość i niespełnienie.

W późniejszej noweli Sienkiewicza Dwie takki, stylizowanej na hinduski apokryf, kraina śmierci jako miejsce wiecznej szczęśliwości została oddzielona od przestrzeni życia „utkaną z ciemności grubą, nieprzeniknioną zasłoną"79. W tym utworze o charakterze parabolicznym objawia się analogiczny jak w realistycznie zarysowanej opowieści o Kamionce proces metamorfozy, polegający na utracie człowieczych kształtów oraz zyskiwaniu przejrzystości i świetlistości, będący warunkiem koniecznym, by ujrzeć zaświatowe uroki, znaleźć się na Łące Śmierci, czyli w Krainie Sziwy. Podobną sytuację przedstawia Sienkiewicz w baśni ateńskiej Diokles, w której przeniknięcie tajemnic wszechświata jest równoznaczne z pozostawieniem na ziemi swych „śmiertelnych szczątków” ${ }^{80}$. W obu parabolach dostrzec można alegoryczne ujęcie prawdy, objawionej wcześniej w miniaturze Lux in tenebris lucet.

Obraz Sienkiewicza jest literackim odbiciem modernistycznych doświadczeń artystów przeżywających nastroje niepewności, zwątpienia, zniechęcenia, doznających klęski na polu działań twórczych i osobistych. Ukazanie załamania utalentowanego człowieka, będącego osobowością o nieprzeciętnych możliwościach twórczych, wprowadza przypadek szczególny, niemniej aspirujący do alegorycznego upostaciowania zasadniczego doświadczenia ludzkiego, wyrażającego się w doznaniu przekleństwa niespełnienia w życiu osobistym i twórczym. Nakreślony przez pisarza stan psychologiczny artysty w sytuacji żałoby, depresji, poszukiwania dróg wyzdrowienia odpowiada konstatacjom naukowym dotyczącym metod odzyskania utraconej kontroli i form uleczenia jaźni uszkodzonej za sprawą utraty bliskiej osoby. Literackie ujęcie dotyka kwintesencji problemu, ale pozwala dostrzec wieloaspektowość dramatu egzystencjalnego człowieka. Nie sposób nie zgodzić się z tezą Zofii Mocarskiej-Tycowej o głębokim osadzeniu twórczości Sienkiewicza w kulturze, co w przypadku uczciwej interpretacji zawartych w niej idei wymusza rozpoznanie szeregu znaków, z jakich została utworzona ${ }^{81}$. Pozwala to nawet w miniaturowej opowieści dostrzegać poruszające umysł i serce arcydzieło.

${ }^{79}$ H. Sienkiewicz, Dwie taki, [w] tenże, Dzieta, t. 5: Nowele, obrazki-przypowieści, Warszawa 1949, s. 270.

${ }^{80}$ H. Sienkiewicz, Diokles, [w:] tenże, Dzieta, t. 5, s. 157.

81 Z. Mocarska-Tycowa, dz. cyt., s. 174. 